\title{
PENGARUH KOMPETENSI GURU DAN KOMITMEN MENGAJAR TERHADAP EFEKTIVITAS PROSES PEMBELAJARAN SERTA IMPLIKASINYA PADA HASIL BELAJAR SISWA DALAM MATA PELAJARAN EKONOMI
}

\author{
Dian Rosdiana \\ Guru Ekonomi SMA Kota Tasikmalaya \\ dian_rosdiana@gmail.com
}

\begin{abstract}
ABSTRAK
Masalah yang menjadi kajian dari penelitian ini adalah mengenai hasil belajar siswa. Inti kajiannya difokuskan pada faktor-faktor yang mempengaruhi hasil belajar, meliputi kompetensi guru, komitmen mengajar, dan efektivitas proses pembelajaran. Berdasarkan hal tersebut, pokok masalah yang diungkap dalam penelitian ini adalah sejauhmana pengaruh kompetensi guru, dan komitmen mengajar, terhadap efektivitas proses pembelajaran serta implikasinya pada hasil belajar siswa baik secara parsial maupun secara bersama-sama. Metode penelitian yang digunakan adalah Explanatory Survey Method, dengan teknik pengumpulan data angket skala lima kategori Likert, terhadap 60 orang guru Ekonomi SMA di Kota Tasikmalaya. Teknik pengolahan data yang digunakan adalah Model Analisis Jalur (Path Analysis Models). Teknik ini digunakan untuk mengetahui hubungan langsung dan tak langsung dari variabel eksogen terhadap variabel endogen. Hasil penelitian ini menunjukkan hasil belajar siswa, efektivitas proses pembelajaran, kompetensi guru dan komitmen mengajar guru Ekonomi SMA di Kota Tasikmalaya termasuk dalam kategori tinggi, dan terdapat pengaruh kompetensi guru dan komitmen mengajar terhadap hasil belajar siswa serta terdapat pengaruh tidak langsung kompetensi guru dan komitmen mengajar terhadap hasil belajar siswa melalui efektivitas proses pembelajaran.
\end{abstract}

Kata kunci: Kompetensi Guru, Komitmen Mengajar, Efrektivitas Proses Pembelajaran, hasil belajar.

\section{ABSTRACT}

The problem that becomes a study in this research was about the students'learning result. Its core study is focused on factors which influenced the learning result, included the teacher's competency, teaching commitment, and effectiveness of learning process. Based on those problems, the center problem that stated in this research is how far the influence of teacher's competency, and teaching commitment through the effectiveness of learning process and its implication on students' learning result whether partially or together. The method that is used in this research is the Explanatory Survey Method, by the technique of collecting data questionnaires on the five category scale of Likert, through 60 person of economic teacher of Senior High School in Tasikmalaya. Meanwhile, the technique of data analysis that is used in this research is the stripe analysis model (Path Analysis Models). This technique is used to know the direct and indirect relationship of exogenous variable through endogenous variable. This result of research showed the students'learning result, the effectiveness of learning process, teacher competency, and the teaching commitment of economic teacher in Senior High School in Tasikmalaya included in high category, and it was contain the teacher influence competency and teaching commitment through the students'learning result also there was an indirect influence of teacher competency and its teaching commitment through the students'learning result pass the effectiveness of learning process.

Keyword: teacher competency, effectiveness of learning process.

\section{PENDAHULUAN}

Permasalahan penelitian ini adalah rendahnya hasil belajar siswa pada mata pelajaran Ekonomi kelas XI IPS SMA di Kota Tasikmalaya. Hal ini dapat dilihat dari hasil studi penelitian yang penulis lakukan terhadap guru Ekonomi SMA di Kota Tasikmalaya. Penyebaran kuesioner pada 60 guru Ekonomi SMA yang diasumsikan sudah bersertifikasi. Fokus pertanyaan adalah sejauhmana pengaruh kompetensi guru dan komitmen mengajar terhadap efektivitas proses pembelajaran serta implikasinya pada hasil belajar? Data hasil olahan dari kuesioner menjelaskan bahwa hasil belajar siswa, efektivitas proses pembelajaran, kompetensi guru dan komitmen mengajar guru Ekonomi SMA di Kota Tasikmalaya termasuk dalam 
kategori tinggi, dan terdapat pengaruh kompetensi guru dan komitmen mengajar terhadap hasil belajar siswa serta terdapat pengaruh tidak langsung antara kompetensi guru dan komitmen mengajar terhadap hasil belajar siswa melalui efektivitas proses pembelajaran.

Dilihat dari sudut proses pendidikan adalah proses dalam rangka mempengaruhi peserta didik supaya mampu menyesuaikan diri sebaik mungkin dengan lingkungannya dan yang akan menimbulkan perubahan pada dirinya yang berfungsi sesuai kompetensinya dalam kehidupan masyarakat. Dengan demikian, pendidikan itu ialah usaha sadar yang dilakukan oleh keluarga, masyarakat dan pemerintah melalui kegiatan bimbingan, pengajaran dan atau latihan yang berlangsung disekolah dan luar sekolah. Usaha sadar tersebut dilakukan dalam bentuk pembelajaran dimana ada pendidik yang melayani para siswanya melakukan kegiatan belajar, dan pendidik menilai atau mengukur tingkat keberhasilan belajar siswa tersebut dengan prosedur yang ditentukan. Siswa yang dikatakan berhasil jika nilai yang diperolehnya memenuhi standar yang telah ditetapkan oleh tiap sekolah yang disebut dengan Kriteria Ketuntasan Minimal (KKM).

Data awal yang diperoleh dari lapangan, yaitu di kelas XI IPS SMA di Kota Tasikmalaya menunjukkan hasil belajar siswa yang diperoleh untuk mata pelajaran Ekonomi pada semester satu belum memenuhi standar KKM. Nilai UAS Ekonomi kelas XI IPS SMA Kota Tasikmalaya memiliki nilai Ekonomi yang rendah. Terbukti bahwa ratarata nilai UAS Ekonomi kelas XI IPS SMA Kota Tasikmalaya yang belum memenuhi standar KKM. Rendahnya hasil belajar siswa menjadi salah satu alasan ketertarikan mengadakan penelitian.

Kajian pustaka dalam penulisan ini adalah; Proses pembelajaran adalah kegiatan yang dilakukan siswa dan guru dalam mencapai tujuan pengajaran. Sedangkan hasil belajar merupakan kemampuan-kemampuan yang dimiliki siswa setelah menerima pengalaman belajarnya. Namun dalam hal ini, hasil belajar siswa merupakan output dari proses pembelajaran yang terjadi di sekolah berkaitan dengan hubungan aktif antara siswa dan guru sehingga dapat menciptakan perubahan perilaku yang positif melalui pembelajaran yang efektif.

Grand teori dalam penelitian ini adalah teori Gagne yang berkeyakinan bahwa belajar dipengaruhi oleh faktor dalam diri (internal) dan faktor luar diri (eksternal) dimana keduanya saling berinteraksi. Penelitian ini akan mengkaji faktor-faktor yang mempengaruhi hasil belajar dari faktor instrumental (guru) yang terdiri dari kompetensi guru dan komitmen mengajar sebagai variabel eksogen, sedangkan faktor learning teaching process yaitu efektivitas proses pembelajaran sebagai variabel intervening dan hasil belajar sebagai variabel endogen.

Berbagai pandangan teoritis dan kajian empiris memperlihatkan bahwa terdapat hubungan positif antara kompetensi guru dan komitmen mengajar terhadap efektivitas proses pembelajaran. Carl Rogers mengemukakan bahawa praktek pendidikan menitik beratkan pada segi pengajaran. Ia menegaskan bahwa profesionalisme guru sangat diperlukan untuk menunjang peningkatan dalam pencapaian hasil belajar. Hal ini, didukung oleh Dunkin dan Biddle (Sagala, S. 2012:23) yang mengatakan proses pembelajaran akan berlangsung dengan baik jika pendidik mempunyai dua kompetensi utama yaitu (1) kompetensi substansi materi pembelajaran atau penguasaan materi pelajaran; dan (2) kompetensi metodologi pembelajaran. Komitmen mengajar indikatornya dari tugas guru menurut Usman, U. (2011:8) yaitu dari segi profesi, kemanusiaan dan kemasyarakatan. Adapun indikator efektivitas proses pembelajaran 
diadopsi dari Sudjana yaitu konsistensi kegiatan belajar mengajar, motivasi belajar siswa, keaktivan para siswa dalam kegiatan belajar dan interaksi guru dan siswa.

Efektivitas proses pembelajaran adalah suatu pembelajaran yang memungkinkan peserta didik untuk dapat belajar dengan mudah, menyenangkan dan dapat tercapai tujuan sesuai dengan harapan. Dengan demikian, pendidik (guru) dituntut untuk dapat meningkatkan keefektifan proses pembelajaran agar hasil belajar optimal serta dapat bermanfaat dan berguna bagi peserta didik.

Penelitian yang menyatakan bahwa kompetensi guru mempengaruhi efektivitas pembelajaran adalah Aryanta (2012), Nurul Aulia (2012), Yayah Pujasari dan Nurdin (anonym). Semua penelitian ini menyatakan bahwa terdapat hubungan positif antara kompetensi guru dengan efektivitas pembelajaran.

Firestone dan Pannell (1993:489) menyatakan bahwa komitmen mengajar guru yang tinggi dalam semua aspek akan berpengaruh positif terhadap prestasi belajar siswa. Penelitian yang menyatakan bahwa komitmen mengajar berpengaruh terhadap hasil belajar siswa adalah Dahlan (2008) dan Akil (2007). Semua penelitian tersebut menyatakan bahwa terdapat hubungan positif antara komitmen guru dan hasil belajar. Serta penelitian Wiwin (2012) menyatakan bahawa komitmen guru berpengaruh positif terhadap produktivitas kerja guru.

\section{METODE PENELITIAN}

Metode penelitian yang digunakan adalah Explanatori Survey Method, dengan tehnik pengumpulan data angket skala lima kategori likert, terhadap 60 guru Ekonomi SMA di Kota Tasikmalaya. Tehnik pengolahan data yang digunakan adalah Model Analysis Jalur (Path Analysis Models). Tehnik ini digunakan untuk megetahui hubungan langsung dan hubungan tidak langsung dari variabel eksogen terhadap variabel endogen. Instrument penelitian dikembangkan berdasarkan indikator masing-masing variabel penelitian. indikator kompetensi guru adalah kompetensi pedagogik dan kompetensi profesional. Kedua, variabel eksogen $\left(\mathrm{X}_{2}\right)$ yaitu komitmen guru. indikator komitmen guru adalah profesi, kemanusiaan dan kemasyarakatan. Ketiga, variabel endogen $\left(\mathrm{Y}_{2}\right)$ yaitu hasil belajar siswa pada mata pelajaran Ekonomi. Indikator hasil belajar siswa adalah nilai rata-rata semester kelas XI IPS dalam mata pelajaran Ekonomi. Keempat, variabel intervening $\left(\mathrm{Y}_{1}\right)$ yaitu efektivitas proses pembelajaran. indikator efektivitas proses pembelajaran adalah (1) konsistensi kegiatan belajar mengajar dengan kurikulum, (2) motivasi belajar siswa, (3) keaktivan para siswa dalam kegiatan belajar, dan (4) interaksi guru dan siswa.

\section{HASIL DAN PEMBAHASAN}

\section{Pengaruh Kompetensi Guru $\left(\mathrm{X}_{1}\right)$ dan Komitmen Mengajar $\left(X_{2}\right)$ Terhadap Efektivitas Proses Pembelajaran $\left(\mathrm{Y}_{1}\right)$.}

Variabel kompetensi guru dan komitmen mengajar secara bersama-sama (Silmutan) berpengaruh terhadap efektivitas proses pembelajaran. Besarnya pengaruh kompetensi guru dan komitmen mengajar terhadap efektivitas proses pembelajaran adalah 0,0487 atau sebesar 4,87\%. Artinya sebesar $4,87 \%$ variasi yang terjadi pada efektivitas proses pembelajaran dapat dijelaskan secara bersama-sama oleh kompetensi guru dan komitmen mengajar. Sisanya sebesar 95,13\% merupakan variabel lain yang tidak terjelaskan model.

Kontribusi kompetensi guru dan komitmen mengajar tidak dominan mempengaruhi efektivitas proses pembelajaran. Hal ini menunjukkan bahwa variabel lain yang tidak diteliti dapat memberikan kontribusi yang besar terhadap efektivitas proses 
pembelajaran sebesar 95,13\%. Sebagaimana kita tahu bahwa efektivitas pembelajaran seperti dijelaskan oleh Slameto (2010:7476), dilihat pada faktor raw input (siswa) yang meliputi faktor internal yaitu kondisi fisiologi siswa, faktor psikis siswa yang meliputi motivasi belajar, perasaan, sikap, minat, kebutuhan akan keamanan dan kondisi akibat keadaan sosiokultural. Selain itu, faktor eksternal lain juga masih banyak mempengaruhi efektivitas pembelajaran siswa diantaranya, kebersihan kelas, penerangan, fasilitas belajar, kurikulum pembelajaran, sarana dan prasarana sekolah dan faktor keluarga.

Jika kita melihat besarnya pengaruh langsung dari masing-masing variabel kompetensi guru terhadap efektivitas proses pembelajaran adalah 0,2419. Artinya jika kompetensi guru meningkat sebesar 1 deviasi standar maka efektivitas proses pembelajaran akan meningkat sebesar 0,2419 atau 5,85\%. Besarnya pengaruh komitmen mengajar terhadap efektivitas proses pembelajaran adalah -0,1010. Artinya jika komitmen mengajar meningkat sebesar 1 deviasi standar maka efektivitas pembelajaran akan meningkat sebesar 0,1010 atau $1,02 \%$. Perhitungan ini menunjukkan bahwa secara langsung pengaruh kompetensi guru terhadap efektivitas pembelajaran lebih besar dibandingkan dengan pengaruh komitmen mengajar terhadap efektivitas proses pembelajaran pada mata pelajaran Ekonomi di SMA Kota Tasikmalaya. Hasil perhitungan model struktural menunjukkan bahwa total pengaruh langsung dari variabel kompetensi guru $\left(\mathrm{X}_{1}\right)$ lebih besar daripada pengaruh langsung komitmen mengajar $\left(\mathrm{X}_{2}\right)$ terhadap efektivitas proses pembelajaran $\left(\mathrm{Y}_{1}\right)$. Hal tersebut menunjukkan bahwa tingginya tingkat efektivitas proses pembelajaran diantaranya ditentukan oleh adanya pengaruh kompetensi guru dan komitmen mengajar. Pengaruh paling besar berada pada kompetensi guru.
Berdasarkan hasil penelitian menunjukkan bahwa kompetensi guru berpengaruh terhadap efektivitas proses pembelajaran pada mata pelajaran ekonomi. Artinya semakin tinggi tingkat kompetensi guru maka efektivitas proses pembelajaran akan semakin kondusif, begitupun sebaliknya. Jika kompetensi guru rendah maka efektivitas proses pembelajaran tidak akan kondusif. Dilihat dari uji hipotesis menunjukkan kompetensi guru tidak berpengaruh terhadap efektivitas proses pembelajaran. Hal ini di prediksi penulis, disebabkan karena rendahnya input (siswa) sebagai subjek dalam pembelajaran SMA di Kota Tasikmalaya, sehingga belum mampu mewujudkan proses pembelajaran yang kondusif. Hal tersebut didukung dengan adanya fakta di lapangan bahwa dari hasil penelitian didapat kompetensi guru Ekonomi SMA di Kota Tasikmalaya dikategorikan tinggi yaitu sebesar 3,79 (75,94\%). Tingkat ketercapaian kompetensi guru berdasarkan setiap indikator diperoleh bahwa indikator kompetensi professional lebih rendah dibandingkan indikator kompetensi pedagogik yaitu sebesar 3,81 (76,20\%). Hal tersebut mempengaruhi penelitian ini bahwa kompetensi guru tidak berpengaruh terhadap efektivitas proses pembelajaran. Hal ini membantah teori yang merujuk pada pendapat Dunkin dan Biddle (Sagala, 2011:23) yang mengatakan proses pembelajaran akan berlangsung dengan baik jika pendidik mempunyai dua kompetensi utama yaitu (1) kompetensi substansi materi pembelajaran atau penguasaan materi pelajaran; dan (2) kompetensi metodologi pembelajaran. Namun berdasarkan perhitungan data, diperoleh koefisien korelasi yang positif antara kompetensi guru dan efektivitas proses pembelajaran yaitu sebesar 0,2005. Artinya terdapat hubungan yang positif antara kompetensi guru dan efektivitas proses pembelajaran.

Dari hasil pengujian data diketahui bahwa komitmen mengajar berpengaruh negative 
terhadap efektivitas proses pembelajaran. Diperoleh koefisien korelasi yang negative antara komitmen mengajar terhadap efektivitas proses pembelajaran yaitu sebesar $-0,0018$. Artinya tidak terdapat hubungan yang positif antara komitmen mengajar terhadap efektivitas proses pembelajaran. Uji hipotesis menunjukkan komitmen mengajar tidak berpengaruh terhadap efektivitas proses pembelajaran. Walaupun secara keseluruhan komitmen mengajar guru yang termasuk pada kategori tinggi, namun ternyata belum mampu menciptakan efektivitas proses pembelajaran. Hal ini bertentangan dengan pendapat seperti dinyatakan Chapman (Dahlan, 2008:67) "commitment to teaching played an important part in determining whether teacher remained in or left the profession, Komitmen mengajar ini sangat penting, sebab akan mempengaruhi komitmen profesinya,". Komitmen mengajar ini, oleh Kusman (Dahlan, 2008:67) dinamakan "commitment to student learning" yang merefleksikan dedikasi guru dalam membantu siswa untuk belajar. Berdasarkan pemaparan tersebut dapat menjadi acuan, seharusnya komitmen mengajar dapat mempengaruhi efektivitas proses pembelajaran. Fakta dilapangan performace guru dalam mengajar tidak sesuai dengan komitmen mengajar yang dimilikinya sebagai contoh guru dalam melaksanakan tugasnya hanya menunaikan haknya sebagai pengajar bukan menunaikan kewajibannya sebagai pengajar yang bertanggung jawab dalam mencerdaskan generasi bangsa. Sehingga dapat ditarik kesimpulan meskipun komitmen mengajar guru yang tinggi namun belum tentu dapat menciptakan efektivitas proses pembelajaran. Hal tersebut didukung dari hasil penelitian diperoleh tingkat ketercapaian komitmen mengajar guru Ekonomi SMA di Kota Tasikmalaya berdasarkan setiap indikator, diperoleh bahwa indikator kemasyarakatan memperoleh hasil paling rendah dibanding indikator lainnya. Indikator ini mengacu pada mendidik dan mengajar masyarakat untuk menjadi warga Negara Indonesia yang bermoral pancasila dan mencerdaskan bangsa Indonesia. Hal ini sebagai alasan mengapa komitmen mengajar guru Ekonomi SMA di Kota Tasikmalaya tidak berpengaruh terhadap efektivitas proses pembelajaran.

\section{Pengaruh Kompetensi Guru $\left(\mathrm{X}_{1}\right)$, Komitmen Mengajar $\left(\mathbf{X}_{2}\right)$ dan Efektifitas Proses Pembelajaran $\left(\mathrm{Y}_{1}\right)$ terhadap Hasil Belajar ( $\left.\mathbf{Y}_{2}\right)$}

Hasil uji kebermaknaan estimasi koefisien jalur menunjukkan ada satu koefisien jalur yang tidak signifikan, yaitu koefisien jalur efektivitas proses pembelajaran ke hasil belajar, koefisen jalur tersebut memberikan nilai tingkat signifikansi (p) sebesar 0,9785 $(\mathrm{p}>0,05)$

Besarnya pengaruh kompetensi guru, komitmen mengajar dan efektivitas proses pembelajaran terhadap hasil belajar adalah 0,6695 atau sebesar $66,95 \%$ artinya sebesar $66,95 \%$ variasi yang terjadi pada hasil belajar dapat dijelaskan secara bersamasama (simultan) oleh kompetensi guru, komitmen mengajar dan efektivitas proses pembelajaran. Pengaruh variabel yang dijelaskan dalam model menunjukkan angka yang sangat besar, artinya bahwa model hasil belajar efektif dijelaskan oleh variabel kompetensi guru, komitmen mengajar dan efektivitas proses pembelajaran. sisanya sebesar 33,05\% merupakan pengaruh variabel lain yang tidak terjelaskan model.

Faktor lain yang mempengaruhi hasil belajar yang tidak diteliti dalam penelitian ini, faktor-faktor tersebut yaitu 1) faktor intern ialah faktor yang ada pada diri individu diantaranya (a) faktor fisikologi (faktor kesehatan, dan cacat tubuh), (b) faktor psikologi (inteligensi, perhatian, minat, bakat, motivasi, kematangan, kemampuan kognitif dan kesiapan) dan (c) faktor kelelahan (kelelahan jasmani dan kelelahan rohani yang bersifat psikis), 2) faktor ekstern ialah faktor yang ada diluar diri individu diantaranya 
faktor lingkungan (a) faktor keluarga (cara orang tua mendidik, relasi antar anggota keluarga, suasana rumah, keadaan ekonomi keluarga dan pengertian orang tua), dan (b) faktor masyarakat (kegiatan siswa dalam masyarakat, mass media, teman bergaul, dan bentuk kehidupan masyarakat). Selanjutnya Faktor instrumental (a) faktor sekolah (metode mengajar, kurikulum, guru, relasi siswa dengan siswa, disiplin sekolah, alat pelajaran, waktu sekolah, standar pelajaran diatas ukuran, keadaan gedung, metode belajar dan tugas rumah). (Djamarah S.B, 2011:176-205; Slameto, 2010:54-72).

Secara parsial besarnya pengaruh efektivitas proses pembelajaran terhadap hasil belajar adalah 0,0021. Artinya jika efektivitas pembelajaran meningkat sebesar 1 deviasi standar maka hasil belajar akan meningkat sebesar 0,0021 atau 0,00041\%. Hal ini berarti efektivitas proses pembelajaran berpengaruh terhadap hasil belajar yang diperoleh siswa. Uji hipotesis menunjukkan nilai $\mathrm{P}=0,9785>$ 0,05 maka dapat dikatakan bahwa efektivitas proses pembelajaran tidak mempengaruhi hasil belajar pada penelitian ini. Hasil belajar yang diperoleh siswa selama satu semester yaitu penggabungan nilai-nilai ulangan harian, ulangan tengah semester, ujian kenaikan kelas, program remedial serta tugas-tugas lainnya. Tidak berpengaruhnya efektivitas proses pembelajaran dikarenakan banyak faktor lain yang mempunyai pengaruh yang lebih besar, seperti pengaruh penilaian subjektivitas guru. sebagai contoh apabila guru tersebut lebih sangat baik sama siswa yang disenanginya meskipun siswa tersebut berprestasi maka yang menjadi fokus guru hanya tertuju pada siswa tersebut dengan mengabaikan kompetensi siswa lain. Sehingga siswa yang lain merasa tidak diakui kemampuanya sebagai perwujudan peningkatan kompetensis dalam proses pembelajaran. Hasil belajar siswa dalam penelitian ini diukur dari nilai raport siswa tidak mencerminkan kompetensi siswa yang sesungguhnya dalam kegiatan pembelajaran. Salah satunya adalah efektivitas proses pembelajaran. Sebagaimana fakta dilapangan bahwa penilaian hanya berfokus kepada hasil belajar akhir berupa nilai yang didapat dari hasil ujian semata, bukan didasarkan kepada efektivitas proses pembelajaran sebagai perwujudan keterlibatan siswa dalam kegiatan pembelajaran. Berdasarkan perhitungan data yang diperoleh koefisien korelasi yang positif antara efektivitas proses pembelajaran terhadap hasil belajar yaitu sebesar 0,1470. Artinya terdapat hubungan positif antara efektivitas proses pembelajaran terhadap hasil belajar siswa.

Besarnya pengaruh kompetensi guru terhadap hasil belajar adalah 0,7245 . Artinya jika kompetensi guru meningkat sebesar 1 deviasi standar maka hasil belajar akan meningkat sebesar 0,7245 atau $52,49 \%$. Besarnya pengaruh komitmen mengajar terhadap hasil belajar adalah 0,1849. Artinya jika komitmen mengajar meningkat sebesar 1 deviasi standar maka hasil belajar akan meningkat sebesar 0,1849 atau $3,42 \%$. Dilihat pada nilai $(\mathrm{P}=* * *<0,05)$ dan $(\mathrm{P}=$ $0,0249<0,05)$ maka dapat dinyatakan bahwa kompetensi guru dan komitmen mengajar berpengaruh secara signifikan terhadap hasil belajar. Kompetensi guru dan komitmen mengajar secara tidak langsung berpengaruh terhadap hasil belajar melalui efektivitas proses pembelajaran masing-masing sebesar 0,0021 atau $0,00041 \%$.

Dalam hal ini, tingkat kompetensi guru dapat memberikan kualitas pembelajaran yang dapat mendukung kinerja guru untuk dapat melaksanakan proses pembelajaran dengan baik. sejalan dengan pendapat Carl Rogers yang mengemukakan praktek pendidikan menitik beratkan pada segi pengajaran. Ia menegaskan bahwa profesionalisme guru sangat diperlukan untuk menunjang peningkatan dalam pencapaian hasil belajar. Memberikan pengaruh positif terhadap hasil belajar siswa yang selanjutnya akan 
berpengaruh terhadap proses pembelajaran. Berdasarkan uraian di atas, kompetensi guru merupakan faktor yang dapat mempengaruhi hasil belajar siswa. Jika seluruh faktor kompetensi guru tersebut melekat kuat dan bernilai positif, maka pengaruhnya akan signifikan terhadap hasil belajar siswa, begitupun sebaliknya. Adapun indikator kompetensi guru yang digunakan dalam penelitian ini menurut Rusman (2011) antara lain kompetensi professional dan kompetensi pedagogik. Setelah dilakukan penelitian maka hasilnya menunjukkah bahwa kompetensi guru Ekonomi SMA di Kota Tasikmalaya berdasarkan setiap indikator tergolong tinggi. kesimpulannya apa yang dipersepsikan guru terhadap kompetensi guru ternyata silakukan guru dalam proses pembelajaran di lapangan. Hal tersebut dibuktikan dnegan adanay pengeruh kompetensi guru terhadap hasil belajar siswa.

Hasil dari penelitian menunjukkan bahwa semakin tinggi tingkat komitmen mengajar, semakin tinggi pula hasil belajar siswa. Uji hipotesis menunjukkan komitmen mengajar berpengaruh terhadap hasil belajar siswa. Tingkat komitmen mengajar yang dipersepsikan guru yang tinggi komitmennya ditandai dengan kuatnya ikatan psikologis dengan sekolah, profesi dan tugas. Bahkan menurut Firestone dan Pennell (Dahlan, 2008:67) guru juga harus memiliki ikatan yang kuat dengan siswa, dan mata pelajaran yang dibinanya. Komitment guru yang tinggi dalam semua aspek tadi akan berpengaruh positif terhadap prestasi belajar siswa. Pada dasarnya tinggi rendahnya hasil belajar yang diraih siswa selain dipengaruhi performance guru dalam mengajar juga banyak dipengaruhi oleh kemampuan itelegensi yang dimiliki siswa. fakta di lapangan terdapat temuan bahwa hasil belajar siswa sebenarnya belum menggambarkan kemampuan intelegensi yang dimiliki siswa maupun kompetensi guru selama menjalani pembelajaran. Fenomena yang terjadi dilapangan justru menunjukkan bahwa nilai hasil belajar yang diukur dari nilai raport, diperoleh dari hasil pengkatrolan nilai seperti tuntutan pemenuhan nilai SKM (Standar Kelulusan Minimum). Sehingga tidak terdapat perbedaan antara siswa dengan tingkat kemampuan intelegensi rendah atau tidak. Sehingga komitmen mengajar tidak memerankan peran penting dalam meningkatkan hasil belajar siswa pada mata pelajaran Ekonomi SMA di Kota Tasikmalaya melalui tanggung jawab guru dalam mencerdaskan kehidupan bangsa.

\section{KESIMPULAN}

Dari hasil penelitian ini menunnjukkan pengaruh kompetensi guru dan komitmen mengajar terhadap efektivitas proses pembelajaran. Artinya semakin tinggi tingkat kompetensi guru dan semakin tinggi tingkat komitmen mengajar maka akan meningkatkan hasil belajar siswa pada mata pelajaran ekonomi. Serta menunjukkan pengaruh kompetensi guru terhadap hasil belajar. artinya semakin tinggi tingkat kompetensi guru maka akan meningkatkan hasil belajar siswa. sedangkan komitmen mengajar dan efektivitas proses pembelajaran tidak berpengaruh terhadap hasil belajar.

\section{DAFTAR PUSTAKA}

Djamarah. (2011). Psikologi Belajar. Jakarta: Rineka Cipta.

Rusman. (2011). Model-model Pembelajaran: Mengembangkan Profesionalisme Guru. Jakarta: Rajawali Pers

Sagala, S. (2012). Konsep dan Makna Pembelajaran. Bandung: Alfabeta

Slameto. (2010). Belajar dan Faktor-faktor yang Mempengaruhi. Jakarta: PT Rineka Cipta.

Sudjana, N. (2011). Penilaian Hasil Proses Belajar Mengajar. Bandung: Rosdakarya 
Usman, U. (2011), Menjadi Guru Profesional. Bandung: PT Remaja. Rosdakarya

Tesis dan Desertasi:

Aryanta, I Gede Putu Agustina. (2012).’Pengaruh Kompetensi Pedagogik dan Kompetensi Profesional Terhadap Mutu Proses Pembelajaran" (studi terhadap guru SMK di kabupaten Tabanan. Tesis. Bandung: Pasca sarjana UPI. 